\title{
Fertilization with monoammonium phosphate in the production of Formosa 'Tainung-01' papaya in the potiguar semiarid
}

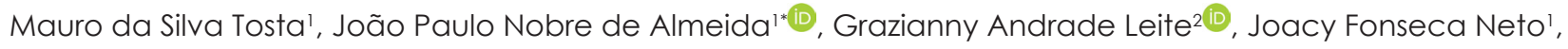 \\ Vander Mendonça' ${ }^{(D)}$, Poliana Samara Castro Freitas' \\ 'Federal Rural University of Semiarid, Mossoró, Brazil \\ ${ }^{2}$ Federal Rural University of Pernambuco, Cabo de Santo Agostinho, Brazil \\ *Corresponding author, e-mail: joaopaulonobre@yahoo.com.br
}

\begin{abstract}
The achievement of good productivity and quality of fruits is directly associated with a balanced fertilization, in which phosphate fertilizers have an important role in the agricultural production system. In this context, this work aimed to evaluate the effect of doses of monoammonium phosphate in ground fertilization and associated with the topdressing in the production of the Formosa "Tainung-01" papaya. The experimental design was in complete randomized blocks, in an split plots outline, having as main factor four fertilizer doses in ground fertilization (0;80; 160, and $250 \mathrm{~kg} \mathrm{ha}^{-1}$ of monoammonium phosphate [MAP]) and, as a sub-portion, two fertilizers in topdressing (20 kg ha-1 of Cosmofert® $+45 \mathrm{~kg} \mathrm{ha}^{-1}$ of MAP" and "90 kg ha-1 of MAP). The harvesting began in the eighth month and extended until the $12^{\text {th }}$ month after transplanting of the seedlings. All fruits of five plants per experimental unit were collected and classified. The number of fruits, the production per plant, the yield, and the percentage of marketable fruits were evaluated. The ground fertilization with the monoammonium phosphate did not influence the production of Formosa 'Tainung-01' papaya fruits exclusively destined to the domestic market. When the production is destined to the external market, a dosage of $74.0 \mathrm{~kg}$ $\mathrm{ha}^{-1}$ of monoammonium phosphate can be used in ground fertilization.
\end{abstract}

Keywords: Carica papaya L., phosphate fertilization, yield

\section{Introduction}

The balanced nutrition for papaya crops is one of the main factors that contribute for the increase in the yield and fruit quality, since it occurs as a function of the amount of each essential element extracted and exported with harvest and the course of nutrient absorption during the plant cycle (Mesquita et al., 2010). In order to attend to this nutritional demand, it is necessary to provide fertilizers in adequate and balanced doses throughout the entire crop cycle (Marinho et al., 2010).

Among nutrients, phosphorus is required in smaller amounts by papaya plants. However, several authors have demonstrated, in their studies, positive results as to the fertilization in fruit species (Nasution et al., 2011; Saraiva et al., 2011; Guimarães et al., 2012; Freitas et al., 2013; Santos et al., 2014; Andrade et al., 2015).

Phosphorus acts in photosynthesis, respiration, storage and transference of energy, cell division, cell growth, and in several other processes in the plant (Leite et al., 2017). This nutrient promotes the premature growth and formation of roots, besides improving fruit quality. Its deficiency decreases the growth of young plants due to the reduction in root development, in the initial stage. High phosphorus contents, in the presence of calcium, might lead to the precipitation of calcium phosphate, which is insoluble (Novais et al., 2007), reducing root growth and multiplication. However, there is the possibility of not occurring a response when performing phosphate fertilization, in which excessive applications of fertilizers might lead to nutritional unbalance, environmental pollution, besides making the practice economically unfeasible.

As a consequence of the high levels of phosphate fertilizer applied, part of the P retained in the solid phase of the soil can become available for the plants over time, constituting a residual effect (Costa et al., 2011). Even with the low efficiency of phosphate fertilization, it is necessary to provide this nutrient to the crops, given its essential role in the vital function of the plants.

In this context, the present work aimed to evaluate the effect of doses of monoammonium phosphate in ground fertilization associated with topdressing fertilization in the production of "Tainung-01" papaya under the edaphoclimatic conditions of the semiarid region of the 
Rio Grande do Norte state.

\section{Material and Methods}

The experiment was installed and conducted in the municipality of Baraúna-RN (geographic coordinates $5^{\circ}$ 04' 31"), in a commercial orchard of the "WG Fruticultura" company, from April 2013 to April 2014.

The harrowing and subsoiling of the soil were performed in the planting row, in which ridges were raised ( $1.6 \mathrm{~m}$ of base width and $30 \mathrm{~cm}$ height), followed by the mounting of the irrigation system using dripping hoses with $20 \mathrm{~mm}$ of diameter and a $0.3 \mathrm{~m}$ spacing between emitters.

Prior to the beginning of the essay mounting, a sample was collected for the chemical analysis of the soil in the planting row, whose values were: $\mathrm{pH}=7.8 ; \mathrm{P}=92.0$ $\mathrm{mg} \mathrm{dm}^{-3} ; \mathrm{K}=229.0 \mathrm{mg} \mathrm{dm}^{-3} ; \mathrm{Ca}=5.1 \mathrm{mmol}_{\mathrm{C}} \mathrm{dm}^{-3} ; \mathrm{Mg}=1.4$ $\mathrm{mmol}_{\mathrm{c}} \mathrm{dm}^{-3} ; \mathrm{CTC}=7.2 \mathrm{mmol}_{\mathrm{c}} \mathrm{dm}^{-3} ; \mathrm{Na}=44.00 \mathrm{mg} \mathrm{dm}^{-3}$; $\mathrm{Fe}=2.6 \mathrm{mg} \mathrm{dm}^{-3} ; \mathrm{Cu}=2.9 \mathrm{mg} \mathrm{dm}^{-3} ; \mathrm{Mn}=14.0 \mathrm{mg} \mathrm{dm}^{-3} ; \mathrm{V}=$ $97.3 \%$ (performed according to the methodology of the EMPARN laboratory, Natal - RN).

Regarding seedling production, Formosa papaya seeds of the "Tainung-01" hybrid were used in the experiment, being sowed in expanded polystyrene trays of 128-cells, transplanting the seeds 21 days after the emergence. The transplantation in simple rows was employed, with 1.250 planting rows $\mathrm{ha}^{-1}$, and a $4 \mathrm{~m}$ spacing between rows and $2 \mathrm{~m}$ between plants. Each row received three papaya seedlings, followed by thinning at flowering, allowing only hermaphrodite plants per row.

During the planting and after the transplantation of the seedlings, $20 \mathrm{~mL}$ of a solution composed by $60 \mathrm{~mL}$ of 'Pole Humus ${ }^{\circledR}$ ' (humic-fulvic solution) were applied via soil, around the base of the plant, to induce the rooting and greater adaptation of the seedlings, along with $40 \mathrm{~mL}$ of 'Aliette Flash ${ }^{\circledR}$ ' (systemic fungicide of the phosphonate group) as a preventive measure to the attack of soil fungi. The applications were performed with a $20 \mathrm{~L}$ backpack sprayer.

A completely randomized block design was used in the experiment, in a scheme of subdivided parcel, having as the main factor four doses of ground fertilization (0; $80 ; 160$, and $250 \mathrm{~kg} \mathrm{ha}^{-1}$ of granular monoammonium phosphate [MAP]) and, as a sub-parcel, two topdressing fertilizations $\left(20 \mathrm{~kg} \mathrm{ha}^{-1}\right.$ of Cosmofert ${ }^{\circledR}+45 \mathrm{~kg} \mathrm{ha}^{-1}$ of MAP and $90 \mathrm{~kg} \mathrm{ha}^{-1}$ of semi-purified and powdered MAP).

The experiment used granular MAP with a 09-4800 formula, whereas the Cosmofert ${ }^{\circledR}$ (liquid) possesses a density of $1.3 \mathrm{~kg} \mathrm{~L}^{-1}$ and a 08-24-00 formula, using ammoniacal nitrogen and phosphorus pentoxide as sources of nitrogen and phosphorus, respectively; besides containing in its formula $7.2 \%$ of organic acids (humic and fulvic acids). The topdressing fertilization was divided into weekly applications in the period from 150 to 210 days after transplantation; each experimental unit consisted of 15 plants, considering the five central plants as a useful plot. $78.2 \mathrm{~kg} \mathrm{ha}^{-1}$ of ammonium sulfate and $31.3 \mathrm{~kg} \mathrm{ha}^{-1}$ of potassium chloride were also added at 217 days after transplantation, through spreading, in a semi-circle of the stem.

Harvesting started in the eighth month and extended until the $12^{\text {th }}$ month after the planting of the seedlings, being performed weekly, in the morning period. All fruits from three plants per experimental unit were collected and classified. The maturation point was the 'color break' stage (stage 2), with a light green husk and two longitudinal yellowish strips. Were considered as disposable (non-marketable) the fruits that presented weight lower than $0.9 \mathrm{~kg}$, and with severe or slight damage for the visual appearance (CEAGESP, 2015).

The fruits considered as external market weighed between $0.9 \mathrm{~kg}$ and $1.3 \mathrm{~kg}$; with a characteristic long shape of the Formosa group. All fruits not classified as neither external market nor non-marketable were put in the internal market group, considering as marketable the summation between the internal and external market. The total corresponded to the result of the summation between the marketable and the non-marketable.

The number of fruits and the production were determined by the cumulative summation of the measured values during the entire harvest, with values expressed in fruit units per plant and kg per plant, respectively. The mean fruit weight was calculated by the division of the production values by the number of fruits, with values expressed in $\mathrm{kg}$ per fruit. For the determination of the yield, the production was multiplied by the number of plants in one hectare $(1,250)$, whose values are expressed in $\mathrm{tha}^{-1}$. The mean fruit weight was determined by the direct division of the production by the number of fruits.

The analyses were performed with the computer software System for Analysis of Variance - SISVAR (Ferreira, 2011). For the variables in which significance was verified $(\mathrm{p}<0.05)$ by the $F$ test, their qualitative means (topdressing fertilizations) underwent Tukey's test ( $p<0.05$ ), whereas the quantitative means (doses of MAP in ground fertilization) were subjected to regression analysis; the regression estimates were performed in the Table Curve ${ }^{\circledR}$ and SISVAR softwares. 


\section{Results and Discussion}

The use of topdressing fertilization for the number of marketable fruits caused a significant effect ( $p<0.05$ ) through the $F$ test, in which the use of Cosmofert ${ }^{\circledR}$ associated with MAP promoted a higher number of marketable fruits, with superiority of $9 \%$, and differed through Tukey's test of the fertilization exclusively with MAP (Table 1).

Table 1. Observed means for the number of fruits (NFr), production (Prod $-\mathrm{Kg}$ plant), and yield (Pde $\left.-\mathrm{tha}^{-1}\right)\left(\mathrm{Ml}_{-}\right.$ internal market; ME - external market; Com - marketable; $T$ - total) in the 'Tainung-01' papaya under topdressing fertilizations (with "Cosmofert ${ }^{\circledR}+M A P "$ and "MAP").

\begin{tabular}{|c|c|c|c|c|c|c|c|c|c|c|c|c|}
\hline \multirow{2}{*}{ Topdressing } & \multicolumn{4}{|c|}{ NFr ${ }^{1}$} & \multicolumn{4}{|c|}{ Prod } & \multicolumn{4}{|c|}{ Pde } \\
\hline & MI & $\mathrm{ME}$ & Com & $\mathrm{T}$ & Ml & $\mathrm{ME}$ & Com & $T$ & $\mathrm{MI}$ & ME & Com & $T$ \\
\hline Cosmofert $^{\circledR}+$ MAP & 54.2 & 11.3 & $65.5 a$ & 86.2 & 90.4 & 16.2 & 106.6 & 122.4 & 113.0 & 20.2 & 133.2 & 149.1 \\
\hline MAP & 49.6 & 11.3 & $60.1 \mathrm{~b}$ & 81.2 & 85.8 & 16.4 & 102.2 & 117.9 & 107.2 & 20.4 & 127.7 & 143.4 \\
\hline IC ( \pm$)$ & 5.5 & 1.1 & 5.9 & 7.0 & 10.2 & 1.8 & 11.0 & 11.7 & 12.8 & 2.2 & 13.8 & 14.4 \\
\hline
\end{tabular}

The use of topdressing fertilization with Cosmofert $^{\circledR}$ associated with MAP did not promote a significant effect through the $F$ test for the percentage of fruits for the internal market and the marketable fruits (Table 2). For the remaining variables, the use of MAP only promoted the highest mean values in the topdressing fertilization, except for the average fruit weight for the internal market, with a mean value of $1.7 \pm 0.1 \mathrm{~kg}$ fruit $^{-1}$. These values are above those observed by Rocha et al. (2007) - of 1.2 kg fruit ${ }^{-1}$.

Table 2. Observed means for the percentage (\%Fr) and average weight (PM Fr - g) ( $\mathrm{Ml}$ - internal market; ME - external market; Com - marketable) of 'Tainung-01' papaya fruits under topdressing fertilizations (with "Cosmofert ${ }^{\boxplus}$ MAP" and with "MAP").

\begin{tabular}{|c|c|c|c|c|c|c|}
\hline \multirow{2}{*}{ Topdressing } & \multicolumn{3}{|c|}{$\% \mathrm{Fr}$} & \multicolumn{3}{|c|}{ PM Fr } \\
\hline & $\mathrm{Ml}$ & ME & Com & $\mathrm{MI}$ & ME & Com \\
\hline Cosmofert $^{\circledR}+$ MAP & 62.0 & 13.5 & 75.5 & 1.7 & 1.4 & 1.6 \\
\hline MAP & 61.0 & 14.3 & 75.4 & 1.7 & 1.5 & 1.7 \\
\hline $\mathrm{IC}( \pm)$ & 2.5 & 1.5 & 2.7 & 0.08 & 0.03 & 0.06 \\
\hline
\end{tabular}

These observed values for fruit weight corroborate the data observed in Linhares (ES), with values from 0.8 to $2.0 \mathrm{~kg}$ fruit $^{-1}$ (Gomes Filho et al., 2008). However, they are below those observed in Cruz das Almas (BA), with mean values of $2.3 \mathrm{~kg}$ fruit ${ }^{-1}$ (Carvalho et al., 2004) and in Limoeiro do Norte (CE), with values from 1.8 to $2.4 \mathrm{~kg}_{\text {fruit }}{ }^{-1}$ (Santos et al., 2008). This superiority might have occurred due to the low number of fruits per plant, causing a greater accumulation of photoassimilates per fruit.

The use of MAP in ground fertilization promoted a significant effect $(p<0.05)$ for the number of fruits. For the internal market, marketable, and total fruits, the absence of phosphate fertilization promoted the highest value, whereas, in the number of fruits destined for the external market, an increment of increasing linear behavior was observed with the increase of the doses of ground fertilization (Figure 1A). The highest estimated value of the fruit number for the internal market was 64.9 fruits plant ${ }^{-1}$, whereas in the marketable fruits it was 73.0 fruits plant $^{-1}$, and the total was 99.3 fruits plant ${ }^{-1}$.

An induced zinc deficiency might have occurred in the soil of the experimental area, promoting a reduction in the number of flowers and roots, which allied to a possible calcium deficiency (Novais et al., 2007), damaged the development of flowers. Therefore, under high doses of MAP, the plant might have presented lower vegetative growth, resulting in a smaller number of fruits, as a function of the reduction in the number of flowers (Santos et al., 2008).

Regarding the number of fruits for the external market, the estimated value was 13.0 fruits per plant, with the application of $250 \mathrm{~kg} \mathrm{ha-1}$ of MAP, representing an increment of $36.0 \%$ when compared with the absence of this $P$ source in ground fertilization. This behavior might have occurred due to the better distribution of photoassimilates since the number of total fruits decreased with the increment in the MAP doses in ground fertilization. These results are above those observed in the municipalities of Linhares - ES (Gomes Filho et al., 2008) and Limoeiro do Norte - CE (Santos et al., 2008), representing only $75.8 \%$ and $19.9 \%$ of the observed in Baraúna, respectively.

In another assay, in Limoeiro do Norte (CE), it represented only $23.7 \%$ of the harvested fruits in Baraúna (Viana et al., 2008), possibly due to the availability of phosphorus in the soil, with a $51.5 \%$ lower amount. It also occurred in an experiment in Cruz das Almas (BA), with values representing only $18.0 \%$ of the number of fruits (Souza et al., 2007), possibly due to a phosphorus limitation, representing only $35.2 \%$ of the average availability of the soil worked in Baraúna (245.3 kg ha-1 of $\left.\mathrm{P}_{2} \mathrm{O}_{5}\right)$. In another 
assay, in the municipality of Cruz das Almas - BA (Carvalho et al., 2004), the authors only observed $17.6 \%$ of the value obtained in the present work, with lower nutrient availability.

The ground fertilization with MAP promoted a significant effect $(p<0.05)$ for the internal market, marketable fruits, and total production (Figure 1B). The absence of ground MAP dosages promoted a higher estimated value for these variables in spite of the topdressing fertilizations employed. The highest estimated value for the internal market production was $109.8 \mathrm{~kg}$ plant; for the marketable fruits it was $122.4 \mathrm{~kg}$ plant, and for the total production it was $140.8 \mathrm{~kg}$ plant. With the use of 80 $\mathrm{kg} \mathrm{ha}^{-1}$ of ground MAP, a loss of $15.5 \%, 19.9 \%$, and $20.1 \%$ occurred in the productions, respectively.

An assay conducted in Linhares (ES) presented a $19.6 \%$ lower estimated production if compared with present work (Gomes Filho et al., 2008). However, the values were above the highest productions observed in Limoeiro do Norte - CE (Santos et al., 2008), which represented only $25.2 \%$ of the observed in Baraúna. Also, in Cruz das Almas - BA (Souza et al., 2007), a production of only $14.3 \%$ of the observed in Baraúna was registered. This difference is possibly due to the phosphorus limiting the

A.

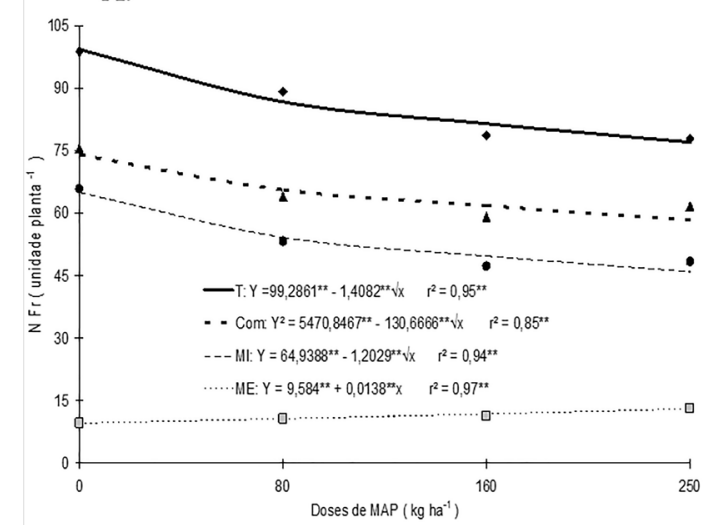

potential of the Tainung $n^{\circ} 01$ hybrid since the available amount in the soil was only $35.2 \%$ (in relation to the assay in Baraúna).

In another assay, in Cruz das Almas (BA), the maximum production of $32.4 \mathrm{~kg} \mathrm{plant}^{-1}$ was verified, representing only $26.4 \%$ of the observed in the present work (Carvalho et al., 2004). The low production can be attributed to the lower availability of available nutrients for plant absorption, which represented only $4.5 \%$ of the total amount of phosphorus in relation to the Baraúna assay.

The use of ground fertilization promoted a significant effect $(p<0.05)$ in the yield destined for the internal market, marketable, and total fruits (Figure $1 C)$, in which the increase in the MAP doses in ground fertilization promoted a negative response for such variables. The absence of ground fertilization promoted an estimated yield of 137.2 ton $\mathrm{ha}^{-1}$ for the internal market, 152.9 ton $\mathrm{ha}^{-1}$ for the marketable fruits, and 171.4 ton $\mathrm{ha}^{-1}$ for the total, observing a reduction of $27.4 \%, 19.9 \%$, and $20.0 \%$ respectively when applying $250 \mathrm{~kg} \mathrm{ha}^{-1}$ of MAP in ground fertilization. The reductions in yield are related to the number of fruits since the fruit weight did not suffer the influence of the treatments.

B.

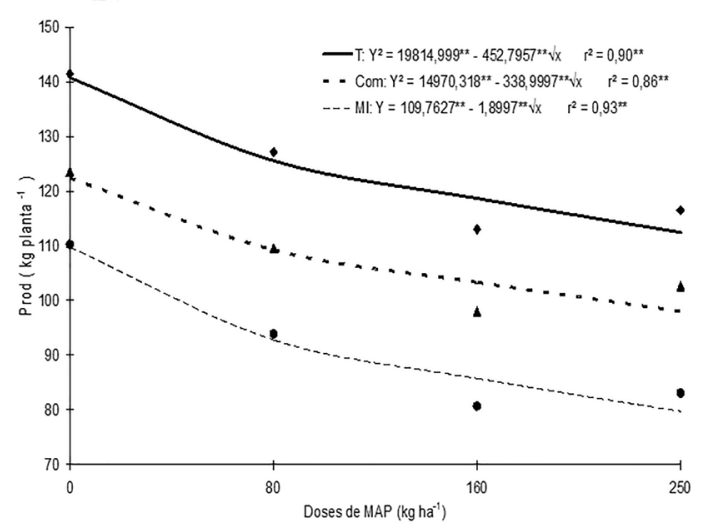

C.

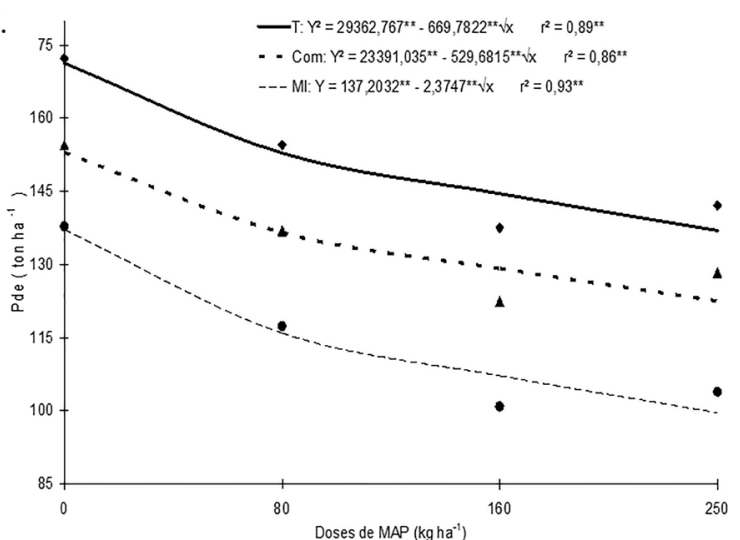

Figure 1. Number of fruits ( $N$ Fr) for the external market (ME), internal market (MI), marketable (Com) and total fruits (T) (A); Production (Prod) for the internal market (MI), marketable fruits (Com), and total fruits (T) (B); and Yield (Pde) for the internal market (MI), marketable fruits (Com) and total fruits (T) (C) of 'Tainung-01' papaya under doses of ground fertilization with monoammonium phosphate (MAP). 
A superior yield in $14.5 \%$ was observed in the conditions of Linhares - ES (Gomes Filho et al., 2008), which might have occurred due to the use of a larger population and a greater agronomical efficiency. Inferior yields to those found in the present work were observed in Cruz das Almas (BA), with values of 30.33 ton ha-1 (Souza et al., 2007) and 53.8 ton ha-1 (Carvalho et al., 2004), and in Limoeiro do Norte (CE), with 42.7 ton ha-1 (Santos et al., 2008). This lower yield might have occurred due to several factors, among them the lower availability of phosphorus for absorption by the plants and/or the edaphoclimatic conditions, in which the plants did express all their productive potential.

Regarding the production for the external market,

A.

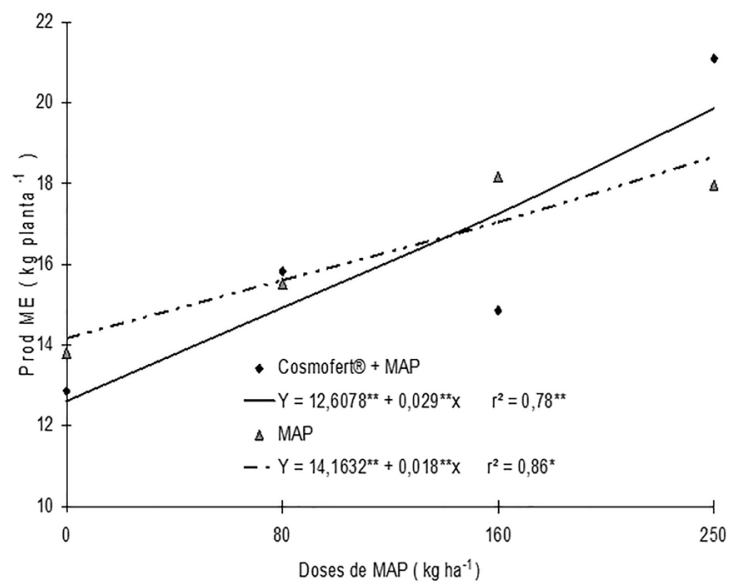

C.

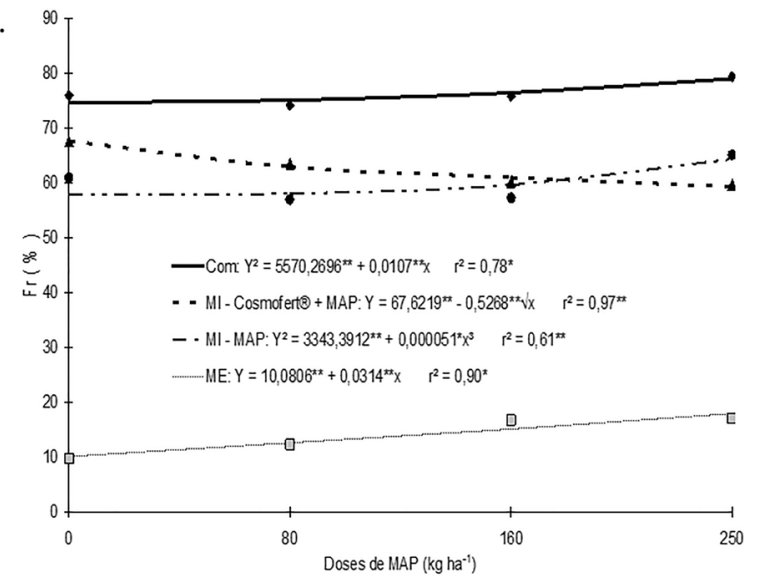

Figure 2. Production for the external market (Prod ME) (A); Yield for the external market (Pde ME) (B); Percentage of fruits (Fr) (C) for the internal market (MI), external market(ME), and marketable fruits (Com) of the 'Tainung-01' papaya under doses of ground fertilization with monoammonium phosphate (MAP) and topdressing fertilizations ("Cosmofer+ +MAP" and "MAP")
Still, in Figure 2A, it is observed that the use of 250 $\mathrm{kg} \mathrm{ha}^{-1}$ of MAP in ground fertilization associated with a topdressing with $90 \mathrm{~kg} \mathrm{ha}^{-1}$ promoted an increment of compared to the control. The unitary increment for the increase in ground fertilization (doses of MAP) was $0.02 \mathrm{~kg}$ in this production. Since the average fruit weight was not influenced by the fertilizations used in this assay, $31.8 \%$ in the production for the external market when there was a significant effect $(p<0.05)$ for the ground and topdressing fertilizations employed (Figure 2A), observing an increment with the increase of the ground MAP doses, with growing linear responses for the topdressing used, in which the use of $250 \mathrm{~kg} \mathrm{ha}^{-1}$ of MAP in ground fertilization associated with the topdressing $\left(20 \mathrm{~kg} \mathrm{ha}^{-1}\right.$ of Cosmofert ${ }^{\circledR}$ $+45 \mathrm{~kg} \mathrm{ha}^{-1}$ of MAP) promoted the highest production (83.1 kg plant ${ }^{-1}$ ), representing a superiority of $6.4 \%$ when using only MAP in topdressing $\left(90 \mathrm{~kg} \mathrm{ha}^{-1}\right)$ and an increment of $57.5 \%$ if compared to the control. For each unitary increase of the ground fertilization with MAP, an estimated increment of $0.03 \mathrm{~kg}$ in the yield was registered for the external market.

B.

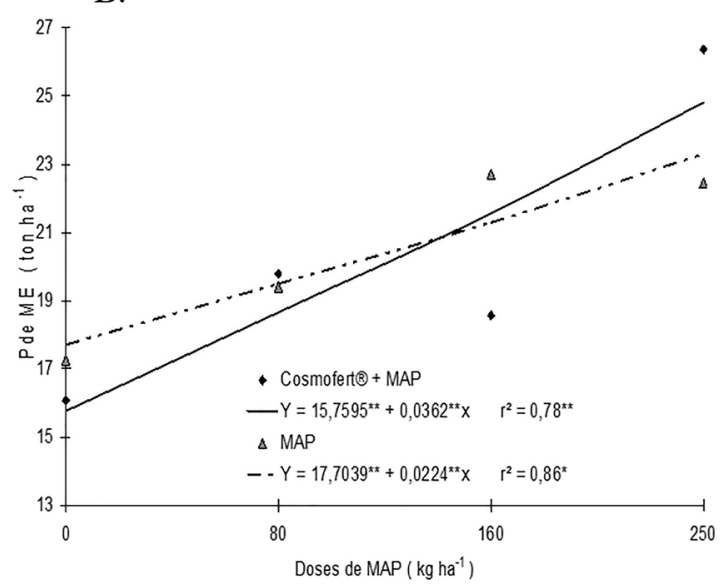

the increase in the number of fruits is responsible for the increment in the production for the external market when increasing the ground fertilization doses with MAP.

For the yield of the external market, there was a significant effect between the ground fertilization and the topdressings used (Figure 2B), observing a growing linear behavior response for all topdressings, directly due to the increase in the number of fruits destined for 
the external market (Figure 1A). The use of $250 \mathrm{~kg} \mathrm{ha}^{-1}$ of MAP associated with a topdressing of " $20 \mathrm{~kg} \mathrm{ha}^{-1}$ of Cosmofert ${ }^{\oplus}+45 \mathrm{~kg} \mathrm{ha}^{-1}$ of MAP" promoted the highest yield for the external market (24.8 ton $\mathrm{ha}^{-1}$ ), presenting an increment of $57.4 \%$ in relation to the MAP in the ground fertilization. When using the topdressing of "90 kg ha-1 of MAP" associated to the application of the maximum studied MAP dose, in the ground fertilization, there was an estimated yield for the external market of $23.3 \mathrm{tha}^{-1}$, representing an increment of $31.6 \%$ in relation to the absence of MAP in ground fertilization. These increments are related to the number of fruits destined for the internal market, since as a function of the reduction in the number of fruits the photoassimilates are transported to a smaller number of fruits, improving their qualitative and quantitative attributes for exportation.

The use of ground fertilization promoted a significant effect $(p<0.05)$ with the topdressings used for the percentage of fruits destined for the internal market (Figure 2C). When using MAP only $\left(90 \mathrm{~kg} \mathrm{ha}^{-1}\right)$ in topdressing fertilization, a growing response was observed in the percentage of fruits destined for the internal market, with a maximum estimated value of $64.3 \%$ with the use of $250 \mathrm{~kg} \mathrm{ha}^{-1}$ of MAP in ground fertilization, representing an increment of $11.3 \%$ in relation to the absence of ground fertilization. This response occurs due to the reduction in the total of fruits, approximately $5 \%$ higher than in the fruits destined for the internal market, thus promoting a percentage increment.

However, when using topdressing fertilization with "Cosmofert ${ }^{+}+$MAP" a reduction in this percentage was observed, in which the absence of MAP in ground fertilization promoted the highest estimated value of $67.6 \%$ of fruits destined for the internal market. However, when using the maximum studied dose, a reduction of $11.7 \%$ was registered (that is, from $67.6 \%$ to $59.3 \%$ ), according to the sketch in Figure $2 \mathrm{C}$. The reduction in the percentage of fruits for the internal market occurred due to the increase in the percentage of fruits destined for exportation, being inversely proportional (Figure 1A).

The use of ground fertilization promoted a significant effect $(p<0.05)$ for the percentage of fruits for the external market and marketable fruits (Figure $2 \mathrm{C})$. Increments with the increase in the doses of ground fertilization were observed, in which the use of the highest studied dose promoted the highest estimated value for these variables. A value of $17.9 \%$ was estimated for the percentage of fruits destined for the external market (for each unitary increase in the MAP applied in ground fertilization, an increment of $0.03 \%$ of fruits was observed), and $79.0 \%$ for the marketable fruits, representing, when compared with the control, an increment of $77.9 \%$ and $5.8 \%$, respectively. The increase in the percentage of fruits for the external market is due to the reduction in the total number of fruits and the increment in the number of fruits destined for the external market. Allied to this behavior, the reduction in large scale in the total of fruits, when compared to the number of marketable fruits, caused an increment in the percentage of marketable fruits.

The results presented here demonstrate that when the contents of phosphorus in the soil are high, the use of fertilization with monoammonium phosphate promoted a reduction in the number of fruits of 'Tainung 01 ' papaya for the internal market, marketable fruits, and total fruits; reduced the production and yield for the internal market, marketable fruits, and total fruits. However, it promoted increments in the number of fruits, production, yield, and percentage of fruits for the external market, besides incrementing the percentage of marketable fruits. This possibility for the producer to spare in the phosphate fertilization when the soil contents are high, contribute highly for the maintaining of the economic viability in irrigated 'Tainung-01' papaya orchards under the conditions of the semiarid region of the Rio Grande do Norte state.

\section{Conclusions}

The ground fertilization with monoammonium phosphate decreased the production of papaya fruits destined exclusively for the internal market.

For the production of 'Tainung-01' papaya fruits destined for the external market, a $74.0 \mathrm{~kg} \mathrm{ha}^{-1}$ dose of monoammonium phosphate associated with the topdressing fertilization is recommended $\left(20 \mathrm{~kg} \mathrm{ha}^{-1}\right.$ of Cosmofert ${ }^{\oplus}+45 \mathrm{~kg} \mathrm{ha}^{-1}$ of MAP).

The topdressing fertilization at the dose of 90 $\mathrm{kg} \mathrm{ha}^{-1}$ of MAP increased the percentage of fruits of 'Tainung-01' papaya destined for the internal market.

\section{References}

Andrade, A.R.S., Cruz, A.F.S., Albuquerque, J.C.F, Godoi Neto, A.H., Silva, J.E.G., Silva, M.M. 2015. Influência de diferentes fontes de fósforo nas características químicas dos frutos do maracujazeiro. Revista Brasileira de Agricultura Irrigada 9: 269-277.

Carvalho, J.E.B., Lopes, L.C., Araújo, A.M.A., Souza, L.S., Caldas, R.C., Daltro Junior, C.A., Carvalho, L.L., Oliveira, A.A.R., Santos, R.C. 2004. Leguminosas e seus efeitos sobre propriedades físicas do solo e produtividade do mamoeiro 'Tainung 1'. Revista Brasileira de Fruticultura 26: 335-338. 
CEAGESP. Companhia de Entrepostos e Armazéns Gerais de São Paulo. 2015. http://www.ceagesp.gov.br/ produtor/classific/<Access on 12 Jan. 2015>

Costa, C.L.L., Batista, J.E., Costa Júnior, C.O., Santos, A.P., Silva, M.L. 2011. Uso de adubo fosfatado na cultura do melão em solos de origem calcária. Revista Verde de Agroecologia e Desenvolvimento Sustentável 6: 58-62.

Ferreira, D.F. 2011. Sisvar: a computer statistical analysis system. Revista Ciência e Agrotecnologia 35: 1039-1042.

Freitas, R.M.O., Nogueira, N.W., Pinto, J.R.S., Tosta, M.S., Dombroski, J.L.D. 2013. Fertilizante fosfatado no desenvolvimento inicial de mudas de pinheira. Bioscience Journal 29: 319-327.

Gomes Filho, A., Oliveira, J.G., Viana, A.P., Pereira, M.G. 2008. Mancha fisiológica e produtividade do mamão Tainung 01: efeito da lâmina de irrigação e cobertura do solo. Revista Ciência e Agrotecnologia 32: 1161-1167.

Guimarães, A.A., Mendonca, V., Nunes, G.H.S., Leite, G.A., Dantas, D.J., Guimarães, A. A. 2012. Adubação fosfatada na produção de goiabeiras 'Paluma' e 'Pedro Sato' no Distrito Irrigado do Baixo AçU/RN. Agropecuária Científica no Semiárido 8: 95-104.

Leite, C.W., Luz, C.A.S., Luz, M.L.G.S., Gadotti, G.I., Renan Navroski, R. 2017. Zonas de manejo nos níveis de fósforo e potássio no solo e a produtividade de arroz irrigado. Revista Engenharia na Agricultura 25: 164-172.

Marinho, A.B., Bernardo, S., Sousa, E.F., Daher, R.F., Carvalho, C.M., Meireles, R.C. 2010. Produtividade e qualidade do fruto do mamoeiro híbrido UENF/ Caliman 01 sob diferentes lâminas de irrigação e doses de potássio. Agropecuária Técnica 31: 22-28.

Mesquita, E.F., Cavalcante, L.F., Gondim, S.C., Campos, V.B., Cavalcante, Í.H.L., Gondim, P.C. 2010. Teores foliares e exportação de nutrientes do mamoeiro Baixinho de Santa Amália tratado com biofertilizantes. Pesquisa Agropecuária Tropical 40: 66-76.

Nasution, F., Noflindawati, M., Budiyanti, T. 2011. The response of five tidal swamp grown papaya cultivars from the collection of the Indonesian tropical fruit research institute (ITFRI) to phosphorus fertilization. Journal of Fruit and Ornamental Plant Research 19: 137-144.

Novais, R.F., Venegas, V.H.A., Barros, N.F., Fontes, R.L.F., Cantarutti, R.B., Neves, J. C.L. (eds.). 2007. Fertilidade do solo. SBCS, Viçosa, Brasil. 1017 p.

Rocha, R.H.C., Menezes, J.B., Nascimento, S.R.C., Nunes, G.H.S. 2007. Qualidade do mamão 'Formosa' submetido a diferentes temperaturas de refrigeração. Revista Caatinga 20: 75-80.

Santos, F.S.S., Viana, T.V.A., Azevedo, B.M., Oliveira, C.W., Sousa, A.E.C. 2008. Efeito de diferentes lâminas de irrigação na cultura do mamão. Revista Brasileira de Engenharia Agrícola 28: 673-680.

Santos, G.P, Lima Neto, A.J., Cavalcante, L.F., Cavalcante, I.H.L., Souto, A.G.L. 2014. Crescimento e produção do maracujazeiro amarelo, sob diferentes fontes e doses de fósforo em cobertura. Bioscience Journal 30: 525-533.

Saraiva, K.R., Nascimento, R.S., Sales, F.A.L., Araújo, H.F., Vieira Fernandes, C.N.V., Lima, A.D. 2011. Produção de mudas de mamoeiro sob doses de adubação fosfatada utilizando como fonte superfosfato simples. Revista Brasileira de Agricultura Irrigada 5: 376-383.

Souza, T.V., Paz, V.P.S., Coelho, E.F., Pereira, F.A.C., Ledo, C.A.S. 2007. Crescimento e produtividade do mamoeiro fertirrigado com diferentes combinações de fontes nitrogenadas. Irriga 12: 563-574.

Viana, T.V.A., Santos, F.S.S., Costa, S.C., Azevedo, B.M.; Sousa, A.E. 2008. Diferentes doses de potássio, na forma de nitrato de potássio, aplicadas via fertirrigação no mamão formosa. Revista Ciência Agronômica 39: 34-38.

Conflict of Interest Statement: The authors declare that the research was conducted in the absence of any commercial or financial relationships that could be construed as a potential conflict of interest.

All the contents of this journal, except where otherwise noted, is licensed under a Creative Commons Attribution License attribuition-type BY. 